\title{
Effect of temperature on inter- and intraspecific isolates of Urotricha (Prostomatida, Ciliophora)
}

\author{
Thomas Weisse $^{1, *}$, David J. S. Montagnes ${ }^{2}$ \\ ${ }^{1}$ Max Planck Institute for Limnology, PO Box 165, D-24302 Plön, Germany \\ ${ }^{2}$ Port Erin Marine Laboratory, University of Liverpool, Port Erin, Isle of Man IM9 6JA, United Kingdom
}

\begin{abstract}
Ecological models often presume that all members of a functional guild, e.g. herbivorous ciliates, respond identically to temperature changes. To test this general assumption, we investigated if planktonic ciliates within the genus Urotricha exhibit distinct inter- and intraspecific responses to temperature. We examined the response of growth rate, cell volume, and production to changing temperature, using 6 temperatures between 5 and $30^{\circ} \mathrm{C}$. This experiment made 3 comparisons using: (1) different species isolated from the pelagic and littoral regions of the same lake; (2) different clones of the same species isolated from lakes of the similar trophic status, but different latitudes; and (3) different clones of the same species isolated from the pelagic region of a single lake. Using ANCOVA and ANOVA procedures $(\alpha=0.05)$ to examine the data we demonstrated that: (1) ciliate species within a single genus may exhibit distinct responses to temperature, suggesting that treating ciliates as a single functional group is an oversimplification; (2) clones isolated from a laboratory culture of a single species, isolated from a single localion, differ only to a small extent; and (3) clones isolated from different localities, but belonging to the same species differ considerably in their responses. Our data indicate that (1) temperature regimes may be an environmental niche that separates species and clones and (2) even where apparent morphological and molecular differences do not distinguish taxa, functional differences may still exist.
\end{abstract}

KEY WORDS: Ciliate. Temperature response Clonal variation - Growth rate Production - Cell volume

\section{INTRODUCTION}

As we become aware of the microbial food web in freshwater systems (see Stockner \& Porter 1988, Weisse 1998), we begin to recognize the need to further characterize the species-specific response of protozoa to abiotic environmental factors. Changes in water temperature affect mixing and stratification and thus constrain the physical environment in many freshwater lakes. Temperature is, however, not only a dominant physical variable but also influences physiological processes of aquatic organisms. As temperature changes both temporally and spatially in lakes, it impacts pelagic food web dynamics, especially those

\footnotetext{
- Present address: Institute of Limnology of the Austrian Academy of Sciences, Gaisberg 116, A-5310 Mondsee, Austria.E-mail: thomas.weisse@oeaw.ac.at
}

processes mediated by the plankton which cannot easily avoid changes. The specificity of the temperature response of pelagic protozoa such as ciliates is, with a few exceptions (e.g. Müller \& Geller 1993), currently unknown.

Considerable growth rate differences with respect to temperature have already been demonstrated within the same ciliate genus (Lee \& Fenchel 1972, Pérez-Uz 1995). In spite of these findings, the potential significance of species-specific physiological differences has been ignored in many ecological investigations. Ecosystem studies which model pelagic systems often group ciliates into size or nutritional categories, and such studies often even apply a single temperature versus growth response for all ciliates (see Montagnes 1996). Modellers commonly presume that all members of one functional guild, e.g. herbivorous ciliates, respond identically to temperature changes (e.g. Gaedke 
\& Straile 1994). To test whether this general assumption is appropriate, we have investigated if ciliates within a single freshwater, planktonic genus exhibit distinct inter-and intraspecific responses to temperature.

In this study we chose to examine small, planktonic, prostome ciliates. It is now recognized that such prostome ciliates, e.g. Urotricha and Balanion, are abundant and often dominant in the plankton, in particular in freshwater lakes (Stoecker \& Evans 1985, Müller et al. 1991, Weisse \& Müller 1998). Typically, the prostomes feed on particles in the range of 5 to $15 \mu \mathrm{m}$ (Müller 1991, Kenter et al. 1996, Weisse \& Müller 1998), making them potential competitors with the other major group of planktonic ciliates, the oligotrich ciliates (Beaver \& Crisman 1989, Müller 1989, Weisse 1998). When food is not limiting and temperature reaches 15 to $20^{\circ} \mathrm{C}$, the prostomes have generation times on the order of 0.5 d (Müller \& Geller 1993, Weisse \& Müller 1998, this study) while many oligotrichs have maximum growth rates near 1 division $\mathrm{d}^{-1}$ (Montagnes 1996), suggesting that prostomes are at times superior competitors.

This study examines the growth and production rates of several isolates of the common prostome Urotricha to test for temperature specificity. We have examined the response to changing temperature at 3 levels by using ciliates isolated from: (1) the pelagic and littoral regions of the same lake; $(2)$ different lakes of the similar trophic status, but different latitudes; and (3) the pelagic region of a single lake.

\section{MATERIALS AND METHODS}

Study organisms. Urotricha species were collected by enriching natural samples with potential prey (Cryptomonas sp. strain 26.80, obtained from the Culture Collection for Algae in Göttingen, Germany). Each Urotricha culture was established by maintaining a mixture of cell isolates that were identified as a single morphotype, i.e. each culture was composed of a single species but, most likely, not of a single clone; these are henceforth referred to as 'mixed clones'. Urotricha furcata was isolated from the pelagic region of Lake Constance (southern Germany) and Lake Schöhee (northern Germany); both lakes are of comparable mesotrophic status (Geller \& Güde 1989, Hofmann 1989) and are $1000 \mathrm{~km}$ apart, $47^{\circ}$ and $54^{\circ} \mathrm{N}$, respectively Urotricha farcta was isolated from the littoral region of Lake Schöhsee.

After mixed clones were established, 3 'true clonal' cultures of Urotricha furcata were isolated from the Lake Constance mixed clone by a minimum of 3 serial, single cell isolations. Note: our clones could have been com- posed of strains best adapted to the laboratory conditions which had outcompeted all other strains. Thus, our results do not test the specific differences between the initially isolated ciliates but examine the potential differences. Furthermore, as rate processes (e.g growth, grazing) are typically estimated from laboratory cultures such as ours, our results reveal the possible errors associated with assuming isolates to be the same.

Prior to the experiment, all ciliate cultures were maintained in WC medium (Guillard \& Lorenzen 1972) containing Cryptomonas sp. strain 26.80, at $10 \mu \mathrm{mol}$ photons $\mathrm{m}^{-2} \mathrm{~s}^{-1}$ and $14 \pm 1^{\circ} \mathrm{C}$. This cryptophyte was formerly named Rhodomonas sp. strain 26.80 (e.g. Müller 1991 ) and has an average cell volume of $-280 \mu \mathrm{m}^{3}$ (Weisse \& Kirchhoff 1997).

Experimental design. For the experiment, the ciliates were grown in the dark in $12 \mathrm{ml}$ capacity, polystyrene, tissue-plate wells, containing 8 to $10 \mathrm{ml}$ of media/prey; the ciliates were always maintained at saturating prey levels $\left(>1 \times 10^{5}\right.$ cells $\mathrm{ml}^{-1}$ for Urotricha spp.; Weisse et al. unpubl.). The prey (Cryptomonas sp.) were grown at $180 \mu \mathrm{mol}$ photons $\mathrm{m}^{-2} \mathrm{~s}^{-1}$ and $14 \pm$ $1^{\circ} \mathrm{C}$ and were harvested in exponential phase for the experiment. We minimised the effect of temperature on food quality by introducing the ciliates into new prey that was adapted to the experimental temperature for only 0.5 to $1 \mathrm{~h}$.

All 6 ciliate isolates (Table 1) were acclimated for $48 \mathrm{~h}$ to 6 temperatures $(5,10,15,20,25$, and $30 \pm$ $0.5^{\circ} \mathrm{C}$ ); ciliates at the extreme temperatures were stepwise acclimated to intermediate temperatures for $1 \mathrm{~h}$, rather than immediately transferring them to the final temperatures. After the $48 \mathrm{~h}$ acclimation, a known number of ciliates was introduced to replicate $(n=3)$ new wells (which contained saturating prey levels for the duration of the experiment), and these wells were incubated for a further $48 \mathrm{~h}$ to determine ciliate growth rates and cell volumes at the 6 temperatures

Ciliate abundance was determined from preserved samples ( $2 \%$ acid Lugol's lodine) by enumerating cells in a Sedgewick-Rafter counting chamber Ciliate volumes were calculated as prolate spheroids from length and width measurements made on 15 to 30 cells (obtained at the end of the experiment), using a semiautomatic SIS ${ }^{\oplus}$ image analysis system. All size measurements were made on Lugol's fixed material which likely underestimates live volume by 60 to $70 \%$ (Jerome et al. 1993, Müller \& Geller 1993). Prey numbers were determined using a CASY 1-model TTC (Schärfe System) electronic particle counter.

Data analysis. Ciliate growth rate $\left(\mu, \mathrm{d}^{-1}\right)$ was determined from end point measurements ( $t_{0}$ and $t_{48}$ ), assuming exponential growth over $48 \mathrm{~h}$. Ciliate production was determined as the product of cell volume and the specific, net, daily change in abundance (i.e. 
net cell volume per day, $\mu \mathrm{m}^{3} \mathrm{~d}^{-1}$ ). ANOVA, $t$-tests, Duncan's multiple range test, and ANCOVA were performed using Statistica 5.1 for Windows $(\alpha=0.05$ for all tests). Data for all tests were homoscedastic ( $\alpha=$ 0.05 , Bartlett chi-squared test). The relationships of (1) growth rate versus temperature and (2) production versus temperature were assumed to be linear over either 5 to $15^{\circ} \mathrm{C}$ or 5 to $20^{\circ} \mathrm{C}$; this assumption is supported by the high $r^{2}$ values for these relationships (Table 1).

For regions of the temperature versus growth and temperature versus production response curves that appeared linear (indicated by regression lines, see Figs. 1 \& 3), ANCOVA comparisons were made between the following groups: the 2 Urotricha species isolated from the same lake but different habitats; the $2 U$. furcata mixed clones isolated from different latitudes; and the $3 U$. furcata true clones isolated from the same lake. Note: as production is the product of growth rate and cell volume, and both of these varied from linearity at high temperatures (see below), the linear portion of the response occasionally differed between treatments. At $25^{\circ} \mathrm{C}$, where the response curves were no longer clearly linear, ANOVA comparisons were made using the same comparisons listed above.

\section{RESULTS}

\section{Growth rate}

The growth rate of all ciliate isolates increased with increasing temperature between 5 and $20^{\circ} \mathrm{C}$, and all ciliates had positive growth rates between 10 and $25^{\circ} \mathrm{C}$ (Fig. 1). At $5^{\circ} \mathrm{C}$ mortality $(\mu<0)$ occurred for most clones, and at $30^{\circ} \mathrm{C}$ only Urotricha farcta grew (Fig. 1)

ANCOVA revealed the following significant differences $(\alpha<0.05)$ in the growth versus temperature responses: mixed clones of Urotricha farcta and U. furcata (both from Lake Schöhee; Fig. 1B, C) had different slopes; the slope of the mixed clones of $U$. furcata from Lake Schöhsee (U. furcata Lake Schöhsee; Fig. 1B) and Lake Constance (U. furcata Lake Constance; Fig. 1A) were not different, but their adjusted means differed; there was no difference between the $3 U$. furcata Lake Constance clones, A, B, and C (Fig. 1D-F).

ANOVA, Duncan's multiple range test, and $t$-tests revealed the following significant differences $(\alpha<0.05)$ in growth rate at $25^{\circ} \mathrm{C}$ : Urotricha farcta Lake Schöhsee $>$ U. furcata Lake Schöhsee; U. furcata Lake Schöhsee $=U$. furcata Lake Constance $i$. furcata clone $A<U$. furcata clone $B=U$. furcata clone $C$.

The parameters for the above regressions and the mean values at $25^{\circ} \mathrm{C}$ are presented in Table 1.

\section{Volume}

The volume of all isolates decreased with increasing temperature, and this response was not clearly linear (Fig. 2). Lake Constance Urotricha furcata isolates were in general larger than the isolate from Lake Schöhsee, and $U$. farcta was larger than U. furcata. These data will be discussed in detail elsewhere, with reference to ciliate volume changes in general (Weisse \& Montagnes unpubl.); here they are presented primarily to establish production responses.

Table 1. Regression parameters of the lines and the mean values of the responses at 25 and $30^{\circ} \mathrm{C}$ (Figs. 1 \& 3 ) for growth and production $\left(\mu \mathrm{m}^{3}\right)$ in estimates of 6 isolates of the genus Urotricha from Lake Schöhsee and Lake Constance. $\mathrm{b}(0)=$ the $y$ intercept; $b(1)=$ the slope; $r^{2}=$ the $r^{2}$ value of the regression. Where analysis of slopes, adjusted mean or means were not significantly different (see 'Results', $\alpha>0.05$ ) a single value is provided for that group; these values are shaded

\begin{tabular}{|c|c|c|c|c|c|c|}
\hline & $\begin{array}{l}\text { U. farcta } \\
\text { L. Schöhsee } \\
\text { Mixed clone }\end{array}$ & $\begin{array}{l}\text { U. furcata } \\
\text { L. Schöhsee } \\
\text { Mixed clone }\end{array}$ & $\begin{array}{l}U . \text { furcata } \\
\text { L. Constance } \\
\text { Mixed clone }\end{array}$ & $\begin{array}{l}\text { U. furcata A } \\
\text { L. Constance } \\
\text { True clone }\end{array}$ & $\begin{array}{l}\text { U. furcata B } \\
\text { L. Constance } \\
\text { True clone }\end{array}$ & $\begin{array}{l}\text { U. furcata C } \\
\text { L. Constance } \\
\text { True clone }\end{array}$ \\
\hline $\begin{array}{l}\text { Equation parameters } \\
\text { of growth versus } \\
\text { temp. response }\end{array}$ & $\begin{array}{l}b(0):-0.422 \\
b(1): 0.108 \\
r^{2} \cdot 0.961\end{array}$ & $\begin{array}{l}b(0):-0.545 \\
b(1): 0.070 \\
r^{2}: 0.833\end{array}$ & $\begin{array}{l}b(0):-0.483 \\
b(1): 0.075 \\
r^{2}: 0.971\end{array}$ & & $\begin{array}{l}b(0):-0.375 \\
b(1): 0.072 \\
x^{2}: 0.928\end{array}$ & \\
\hline Growth at $25^{\circ} \mathrm{C}\left(\mathrm{d}^{-1}\right)$ & 1.79 & \multicolumn{2}{|c|}{0.914} & 0.905 & \multirow{2}{*}{\multicolumn{2}{|c|}{1.20}} \\
\hline Growth at $30^{\circ} \mathrm{C}\left(\mathrm{d}^{-1}\right)$ & 1.75426 & & & No growth & & \\
\hline $\begin{array}{l}\text { Equation parameters } \\
\text { of net production } \\
\text { versus temp. response }\end{array}$ & $\begin{array}{l}b(0):-1870 \\
b(1): 475 \\
\mathrm{I}^{2} \cdot 0.839\end{array}$ & $\begin{array}{l}b(0):-645 \\
b(1): 89.9 \\
r^{2}: 0.866\end{array}$ & $\begin{array}{l}b(0):-863 \\
b(1): 144 \\
\mathrm{r}^{2}: 0.893\end{array}$ & & $\begin{array}{l}b(0):-1150 \\
b(1): 203 \\
r^{2}: 0.902\end{array}$ & \\
\hline Net production at $25^{\circ} \mathrm{C}$ & 8720 & 1140 & 1750 & & 2290 & \\
\hline Net production at $30^{\circ} \mathrm{C}$ & 8860 & & & No production & & \\
\hline
\end{tabular}



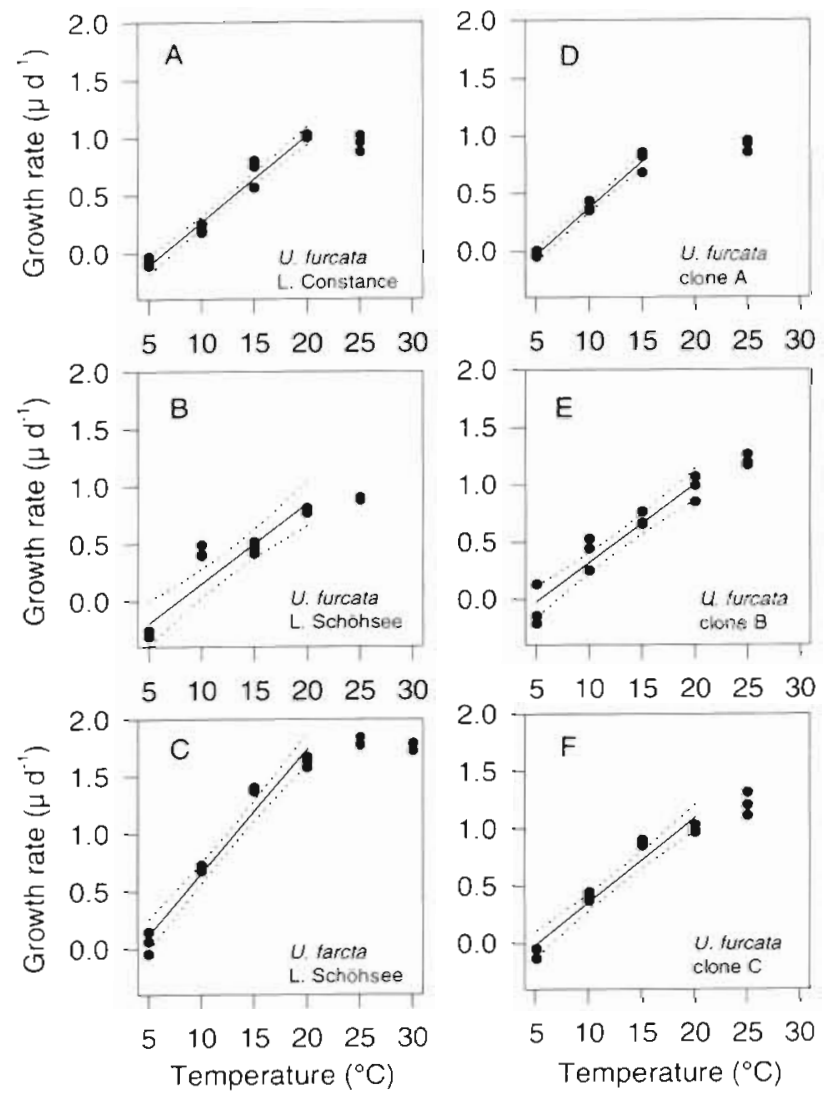

Fig. 1. Response of growth rate $\left(\mu_{1} \mathrm{~d}^{-1}\right)$ to temperature for 6 isolates of Urotricha: (A) $U$. furcata mixed clone from the pelagic region of Lake Constance; (B) U. furcata mixed clone from the pelagic region of Lake Schöhsee; (C) U. farcta mixed clone from the littoral region of Lake Schöhsee $(D-F)$ true clones $\mathrm{A}, \mathrm{B}$, and $\mathrm{C}$ of $U$. furcata, respectively, isolated from the Lake Constance mixed clone. Regressions (solid lines) were determined using data that showed a constant increase with temperature. Dashed line: $95 \%$ confidence interval of the regression. No data were available for $U$. furcata clone $\mathrm{A}$ at $20^{\circ} \mathrm{C}$ (Fig. $1 \mathrm{D}$ )

\section{Production}

The production of all ciliate isolates increased with increasing temperature between 5 and $15^{\circ} \mathrm{C}$ or 5 and $20^{\circ} \mathrm{C}$, and production was positive for all ciliates between 10 and $25^{\circ} \mathrm{C}$ (Fig. 3). At $5^{\circ} \mathrm{C}$ production was negative for most clones (Fig. 3). ANCOVA revealed the following significant differences $(\alpha<0.05)$ in the production versus temperature responses: mixed clones of Urotricha farcta Lake Schöhsee and U. furcata Lake Schöhsee (Fig. 3B, C) had different slopes; $U$. furcata Lake Schöhsee and $U$. furcata Lake Constance had different slopes (Fig. 3A, B); there was no difference between the $3 U$. furcata Lake Constance clones, A, B, and C (Fig. 3D-F).
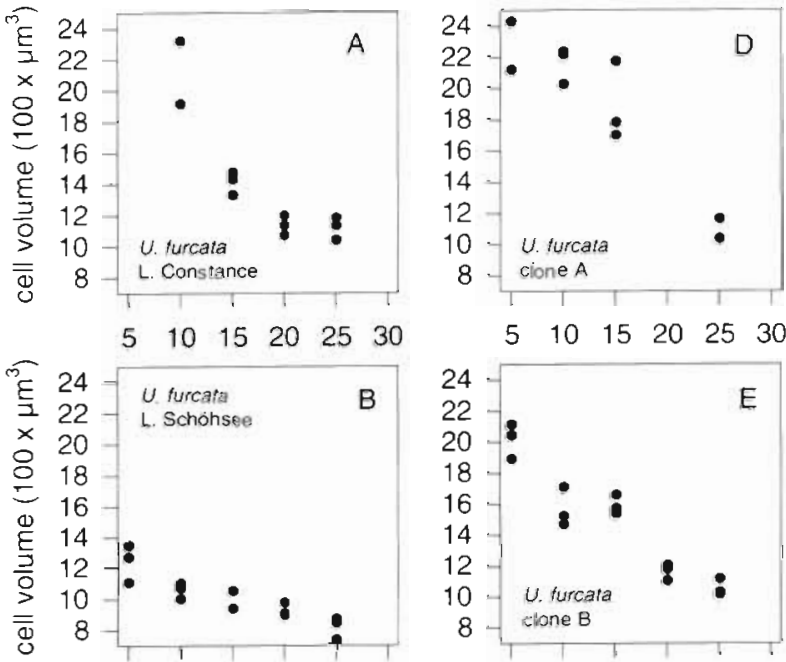

$\begin{array}{llllll}5 & 10 & 15 & 20 & 25 & 30\end{array}$

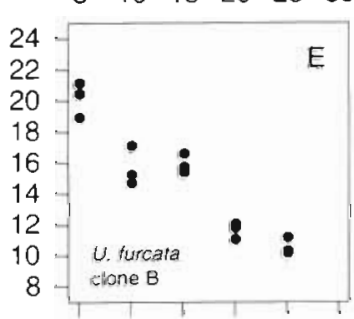

$\begin{array}{llllll}5 & 10 & 15 & 20 & 25 & 30\end{array}$
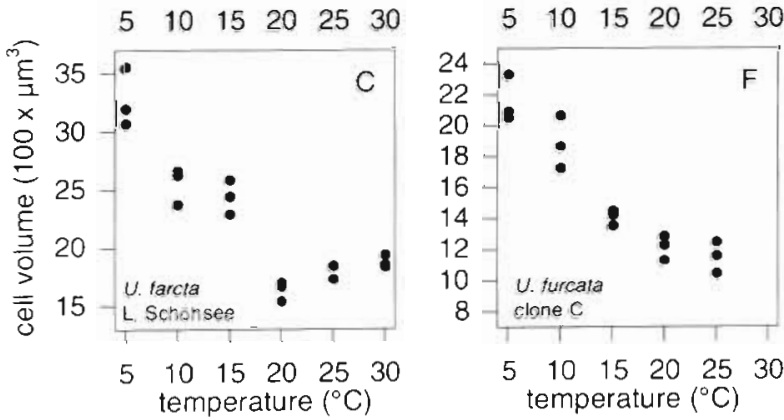

Fig. 2. Response of ciliate cell volume $\left(\mu \mathrm{m}^{3} \times 100\right)$ to temperature for 6 isolates of Urotricha: (A) U. furcata mixed clone from the pelagic region of Lake Constance; (B) U. furcata mixed clone from the pelagic region of Lake Schöhsee; (C) U. farcta mixed clone from the littoral region of Lake Schöhsee; (D-F) true clones $\mathrm{A}, \mathrm{B}$, and $\mathrm{C}$ of $U$. furcata, respectively, isolated from the Lake Constance mixed clone

ANOVA, Duncan's multiple range test, and $t$-tests revealed the following significant differences $(\alpha<0.05)$ in production at $25^{\circ} \mathrm{C}$ : Urotricha farcta Lake Schöhsee $\gg$ mixed clone Urotricha furcata Lake Schöhsee; U. furcata Lake Schöhsee < U. furcata Lake Constance; $U$. furcata clone $\mathrm{A}=U$. furcata clone $\mathrm{B}=U$. furcata clone $\mathrm{C}$.

The parameters for the production versus temperature regressions and the mean production values at $25^{\circ} \mathrm{C}$ are presented in Table 1.

\section{DISCUSSION}

\section{Is there one temperature response curve per species?}

Temperature affects both growth rate (e.g. Müller \& Geller 1993) and cell size (Atkinson 1994) of ciliates and our data support this observation. Thus, variation in temperature is an important factor to consider when 
examining freshwater ciliate ecology. This holds in particular for estimating ciliate production which depends on both growth rate and the individual cell size (see 'Why examine growth rate $(\mu)$ and production?' below).

It is commonly assumed that the temperature dependent growth rate of a given species can be represented by a single curve. Ecosystem studies which model pelagic systems often group protists (e.g. ciliates) into size or morphotype categories, and such studies often then apply a single temperature versus growth response for all ciliates (see Montagnes 1996). Our study may challenge this assumption. To test for temperature specificity we have examined the response to changing temperature of ciliates isolated from: (1) the pelagic and littoral regions of the same lake (Urotricha furcata and $U$. farcta, respectively); (2) different lakes of similar trophic status, but different latitudes ( $U$. furcata from Lakes Constance and Schöhsee); and (3) the pelagic region of a single lake ( $U$. furcata clones $\mathrm{A}, \mathrm{B}$, and $\mathrm{C}$ ).

We have demonstrated that ciliate species within a single genus may exhibit distinct responses to temperature, suggesting that treating ciliates as a single functional group may be an oversimplification. We have also demonstrated that clones isolated from a laboratory culture of a single species, isolated from a single location, differ only to a small extent (Table 1). This is not surprising, since laboratory cultures maintained for many generations will select for a reduced number of adapted strains. Of greater interest, however, is that clones isolated from different localities but belonging to the same species differ considerably in their responses (Table 1). Thus, our data show that even where morphological and obvious molecular differences (see below) do not distinguish taxa, functional differences may still exist.

\section{Potential for inter- and intraspecific ecological differences in Urotricha}

Lakes possess regions where temperature is relatively stable and others where it varies considerably, and regions of relatively high and low temperature occur within and between lakes. Many ciliate species and genera have cosmopolitan distributions (Finlay 1990. Finlay et al. 1996) and will consequently experience a range of temperature conditions. At the same time morphologically indistinguishable populations can be sufficiently isolated to allow genetic divergence (Finlay 1990, Dini \& Nyberg 1993). Thus, differing temperature regimes should create niches for ciliate species and clones; such clonal diversity is common in other freshwater taxa that reproduce primarily asexu-
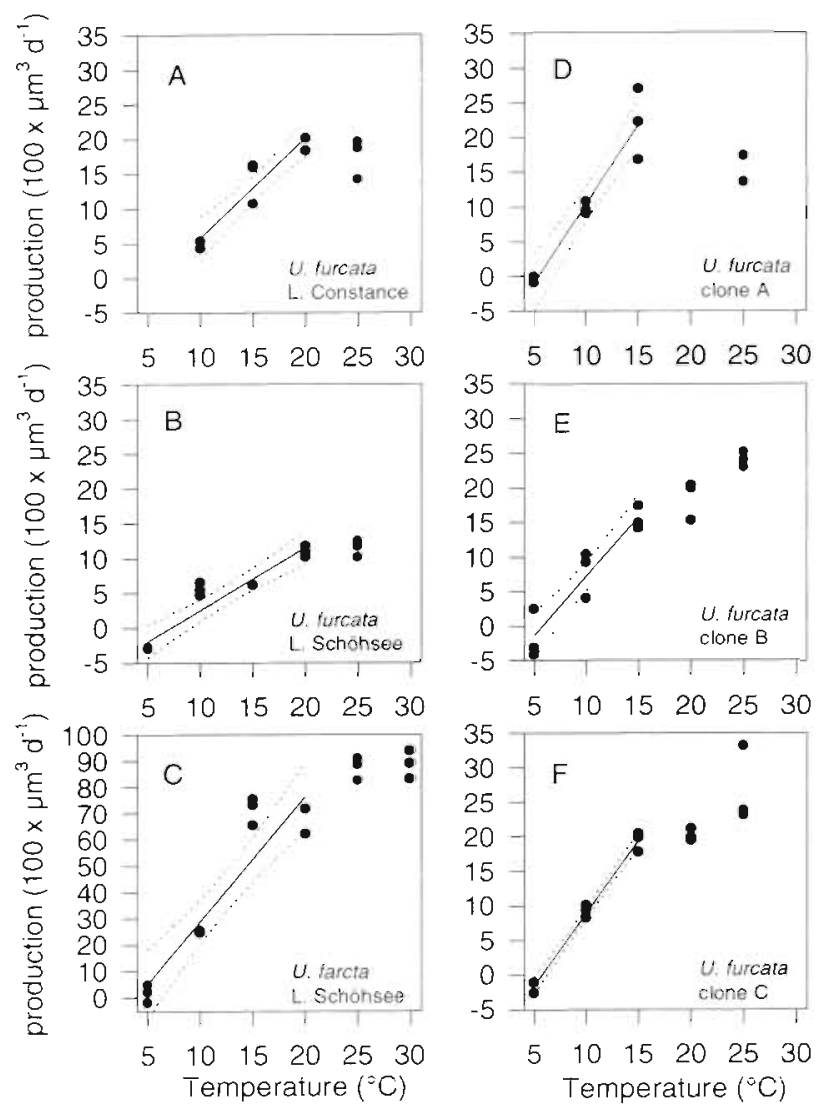

Fig. 3. Response of net production of cell volume $\left(\mu \mathrm{m}^{3}, \mathrm{~d}^{-1}\right)$ to tempcrature for 6 isolates of Urotricha: (A) U. furcata mixed clone trom the pelagic region of Lake Constance; (B) U. furcata mixed clone from the pelagic region of Lake Schöhsee; (C) U. farcta mixed clone from the littoral region of Lake Schöhsee; (D-F) true clones $A, B$, and $C$ of $U$. furcata, respectively, isolated from the Lake Constance mixed clone. Regressions (solid lines) were determined using data that showed a constant increase with temperature. Dashed line: $95 \%$ confidence interval of the regression

ally (reviewed by Carvalho 1994, De Meester 1996). Considerable growth rate variability has already been reported for marine ciliates isolated from different localities (Pérez-Uz 1995). Ours is the first study to indicate how sympatric, coexisting, freshwater ciliates react to temperature changes.

Urotricha furcata and $U$. farcta coexist in small lakes in northern Germany (Skibbe 1991 in Foissner et al. 1994) and Denmark (Jürgens et al. unpubl.), and both species are considered cosmopolitan (Foissner et al. 1994). Although they have different cell volumes (Fig. 2), these 2 species are similar in appearance, and even a trained observer would have difficulties identifying them in a typical plankton sample. Only advanced taxonomic techniques, e.g. silver staining (Foissner 1994) and molecular methods such as dena- 
turing gradient gel electrophoresis and ssu-rDNA sequencing, have distinguished these species (Bruchmüller 1998). However, there are significant ecological differences between $U$. furcata and $U$. farcta: (1) they differ in their ability to grow at 25 and $30^{\circ} \mathrm{C}$ and (2) they differ in the slopes of their growth and production responses to temperature (Figs. 1 \& 3, Table 1). Data suggest that at saturating food concentrations ( $1.2 \mathrm{mg} \mathrm{C} \mathrm{ml} \mathrm{me}^{-1}$, Weisse et al. unpubl.) U. furcata is the less successful competitor, with lower growth and production rates at all temperatures and a poor ability to cope with high temperatures (Table 1). However, these 2 species likely occupy different spatial niches.

Urotricha farcta is euryokous, i.e. it is able to live under widely varying environmental conditions. $U$. farcta occurs in ponds, lakes, and rivers throughout the year, and it is abundant in eutrophic and hypertrophic waters; in these waters temperature varies between 0 and $36^{\circ} \mathrm{C}$ (Foissner 1994). U. furcata occurs in hypertrophic lakes (Foissner et al. 1994, Jürgens et al. unpubl.) and eutrophic reservoirs (Šimek et al. 1995, Macek et al. 1996) as well as in some rivers and creeks (Foissner et al. 1994), but appears to be typically found in oligo-eutrophic lakes (Müller 1991, Sommaruga \& Psenner 1993, Schönberger 1994); these locations are likely to have a limited temperature range compared to the large range that $U$. farcta experiences. Thus, although these 2 species may co-occur (Skibbe 1991 in Foissner et al. 1994), there is some evidence to suggest they occupy different 'temperature niches'; this agrees with our findings. Similar interspecific differences with respect to temperature occur for the coexisting prostomes U. furcata and Balanion planctonicum (Müller et al. 1991, Sommaruga \& Psenner 1993, Schönberger 1994) from both laboratory (Müller \& Geller 1993) and field investigations (Weisse \& Müller 1998). Thus, niche separation with respect to temperature may be common in closely related, coexisting prostome ciliates.

\section{Why examine growth rate $(\mu)$ and production?}

The intrinsic rate of increase $(\mu)$ is often used as the dependent variable when determining temperature versus rate responses (e.g. Müller \& Geller 1993, Montagnes 1996). Growth rate provides information useful for estimating population dynamics. For instance, from data presented in Table 1 we can show that at $25^{\circ} \mathrm{C}$ a single cell of Urotricha farcta from Lake Schöhsee would produce 5 new cells in $1 \mathrm{~d}$ while a population of $U$. furcata from the same lake would only produce 1.5 cells. In contrast, the new volume that these 2 ciliates produced in $1 \mathrm{~d}$ would be 8720 and $1140 \mu \mathrm{m}^{3}$ for $U$. farcta and $U$. furcata, respectively (Table 1). Note that there is a 3.3 -fold difference in the increase in numbers and a 7.6 difference in the potential production.

Considerable changes in the average cell volume of ciliates with temperature have been known for some time (Lee \& Fenchel 1972). Details of the volume changes among Urotricha and other pelagic ciliates and their significance for production estimates will be reported elsewhere (Montagnes et al. unpubl., Weisse \& Montagnes unpubl.).

It is appropriate to use growth estimates when studying population growth and the subsequent dispersal of clonal organisms like ciliates; such information might be used to assess the exploitative ability of an organism. However, in studies where the main interest is in the amount of biomass available for transfer within the food web, production is a more appropriate measurement.

\section{CONCLUSIONS}

The above data support the prediction that different species within a genus behave differently, but they also indicate that clones that are morphologically indistinguishable may also differ. These differences may seem minor, but ciliates like Urotricha may double several times per day, and small initial differences between species or clone abundance will rapidly be amplified by exponential population growth. Therefore, we must be aware of this natural variability, and the growth response of Urotricha to temperature exemplifies such differences.

How then can we apply our awareness of clonal variations in growth and production rates? Besides recognizing the evolutionary implications of natural variation, which in themselves are intriguing, awareness of these responses might be applied to ecosystem models. However, it will be impractical for modellers to consider all the permutations of clonal (and even species) variability. We instead suggest that models should not only consider mean values but also the range of variation in response to a given abiotic parameter, i.e. the reaction norm. Future studies should pay more attention to the extremes at both ends of the reaction norm since natural selection will annihilate the worst adapted and favour the best adapted specimens within a population.

Acknowledgements. We thank: H. Müller and K. Jürgens for supplying the $U$. furcata isolates; B. Stammer for helping to measure cells; L. Janke and N. Karstens for maintaning cultures; and $W$. Foissner for identifying the $U$. farcta isolate. Three anonymous reviewers offered constructive criticism on the manuscript. We also thank the Max-Planck-Society for providing funds to allow D.J.S.M. to visit the Institute. 


\section{LITERATURE CITED}

Atkinson D (1994) Temperature and organism size-- $\overline{\mathrm{a}}$ biological law for ectotherms? Adv Ecol Res 25:1-58

Beaver JR, Crisman TL (1989) The role of ciliated protozoa in pelagic freshwater ecosystems. Microb Ecol 17: $111-136$

Bruchmüller I (1998) Molekularbiologische Charaktensıerung und phylogenetische Einordnung dominanter heterotropher Nanoflagellaten und prostomatider Ciliaten des Süßwassers. PhD thesis, University of Kiel

Carvalho GR (1994) Evolutionary genetics of aquatic clonal invertebrates: concepts, problems and prospects. In Beaumont AR (ed) Genetics and evolution of aquatic organisms. Chapman \& Hall, London, p 291-323

De Meester L (1996) Local genetic differentiation and adaptation in freshwater zooplankton populations: patterns and processes. Ecoscience 3:385-399

Dini F, Nyberg D (1993) Sex in ciliates. In: Jones JG (ed) Advances in microbial ecology, Vol 13. Plenum Press, New York, p 129-144

Finlay BJ (1990) Physiological ecology of free-living protozoa. In: Marshall KC (ed) Advances in microbial ecology, Vol 11. Plenum Press, New York, p 1-35

Finlay BJ, Corliss JO, Esteban G, Fenchel T (1996) Biodiversity at the microbial level: the number of free-living ciliates in the biosphere. Q Rev Biol 71:221-237

Foissner W (1994) Progress in taxonomy of freshwater ciliates. Mar Microb Food Webs 8:9-35

Foissner W, Berger H, Kohmann F (1994) Taxonomische und ökologische Revision der Ciliaten des Saprobiensystems. Band III: Hymenostomata, Prostomatida, Nassulida Informationsberichte des Baycrischen Landesamtes für Wasserwirtschaft 1:469-472

Gaedke U, Straile D (1994) Seasonal changes of the quantitative importance of protozoans in a large lake. An ecosystem approach using mass-balanced carbon flow diagrams. Mar Microb Food Webs 8:163-188

Geller W, Güde H (1989) Lake Constance - the largest German lake. In: Lampert $W$, Rothhaupt KO (eds) Limnology in the Federal Republic of Germany. Carius, Kiel, p 9-17

Guillard RRL, Lorenzen CJ (1972) Yellow-green algae with chlorophyllide c. J Phycol 8:10-14

Hofmann W (1989) Holstein lakes. In: Lampert W, Rothhaupt KO (ed) Limnology in the Federal Republic of Germany. Carius, Kiel, p 41-45

Jerome CA, Montagnes DJS, Taylor FJR (1993) The effect of the quantitative protargol stain and Lugol's and Bouins's fixatives on cell size: a more accurate estimate of ciliate species biomass. J Eukaryot Microbiol 40:254-259

Kenter U, Zimmermann U, Müller H (1996) Grazing rates of the freshwater ciliate Balanion planctonicum determined by flow cytometry. J Plankton Res 18:1047-1053

Lee CC, Fenchel T (1972) Studies on ciliates associated with sea ice from Antarctica. II. Temperature responses and

Editorial responsibility: Karel Simek,

Céské Budějovice, Czech Republic tolerances in ciliates from Antarctic, temperate and tropical habitats. Arch Protistenkd 114:237-244

Macek M. Simek K, Pernthaler J, Vyhnálek V, Psenner R (1996) Growth rates of dominant planktonic ciliates in two freshwater bodies of different trophic degree. J Plankton Res 18:463-481

Montagnes DJS (1996) Growth responses of planktonic ciliates in the genera Strobilidium and Strombidium. Mar Ecol Prog Ser 130:241-254

Müller $H$ (1989) The relative importance of different ciliate taxa in the pelagic food web of Lake Constance. Microb Ecol 18:261-273

Müller H (1991) Pseudobalanion planctonicum (Ciliophora, Prostomatida): ecological significance of an algivorous nanociliate in a deep meso-eutrophic lake. J Plankton Res $13: 247-262$

Müller H, Geller W (1993) Maximum growth rates of aquatic ciliated protozoa: the dependence on body size and temperature reconsidered. Arch Hydrobiol 126:315-327

Müller H, Schöne A, Pinto-Coelho RM, Schweizer A, Weisse $T$ (1991) Seasonal succession of ciliates in Lake Constance. Microb Ecol 21:119-138

Pérez-Uz B (1995) Growth rate variability in geographically diverse clones of Uronema (Ciliophora: Scuticociliatida) FEMS Microbiol Ecol 16:193-204

Schönberger M (1994) Planktonic ciliated protozoa of Neusiedler See (Austria/Hungary) - a comparison between the turbid open lake and a reedless brown-water pond Mar Microb Food Webs 8:251-263

Simek K, Bobkovà J, Macek M, Nedoma J, Psenner R (1995) Ciliate grazing on picoplankton in a eutrophic reservoir during the summer phytoplankton maximum: a study at the species and community level. Limnol Oceanogr 40: $1077-1090$

Sommaruga R, Psenner R (1993) Nanociliates of the order Prostomatida: their relevance in the microbial food web of a mesotrophic lake. Aquat Sci 55:179-187

Stockner JG, Porter KG (1988) Microbial food webs in fresh water planktonic ecosystems. In: Carpenter SR (ed) Complex interactions in lake communities. Springer, New York, p 69-83

Stoecker DK, Evans GT (1985) Effects of protozoan herbivory and carnivory in a microplankton food web. Mar Ecol Prog Ser 25:159-167

Weisse I (1998) Pelagic microbes-Protozoa and the microbial food web. In: O'Sullivan P, Reynolds CS (ed) The lakes handbook, Vol 1. Blackwell Science Ltd, Oxford (in press)

Weisse T, Kirchhoff B (1997) Feeding of the heterotrophic freshwater dinoflagellate Peridiopsis berolinense on cryptophytes: analyses by flow cytometry and electronic particle counting. Aquat Microb Ecol 12:153-164

Weisse T, Müller H (1998) Planktonic protozoa and the microbial food web in Lake Constance. Arch Hydrobiol Spec Issues Adv Limnol (in press)

Submitted: December 12, 1997; Accepted: April 29, 1998

Proofs received from author(s): August 10, 1998 